schot:; Migros-Genossenschafts-Bund; Nationale Coöperatieve Raad, Centrale Vereniging voor de Coöperatieve Handel, Centrale Vereniging voor de Coöperatieve Industrie; De Nederlandsche Bank N.V.; Nederlandsche Siemens Mij. N.V.; Nederlandse Spoorwegen N.V.; N.V. Rubberfabriek Vredestein; Spaarbank voor de Stad Amsterdam; Stoomvaart Maatschappij Nederland N.V.

\title{
UIT DE ECONOMIST VAN 1868
}

- De wetenschap heeft een zwaar verlies geleden. - Onder het afdrukken dezer laatste bladzijden vernemen wij de smartvolle tijding van het overlijden van Mr. O. van Rees, hoogleraar te Utrecht.

Geliefd discipel van Ackersdijck, heeft hij diens plaats met eere vervuld. Kon het anders, met het warm en edel gemoed, den vurigen waarheidszin en zeer groote liefde voor studie, waarmede hij bezield was? Van die kwaliteiten droegen ook zijne geschriften de duidelijke kenteekenen. Zoo als daaruit blijkt waren de koloniale onderwerpen, nevens de veelvuldige bezigheden aan zijn hoogleeraarsambt verbonden, meer en meer zijn lievelingsstudie geworden; doch daarbij werd hij ook zeer aangetrokken door alles wat volksbeschaving in het algemeen betreft, en de gewigtige zaak der arbeiders-vereenigingen en coöperatiën werd meermalen zoo in voordragten als in geschriften con amore door hem behandeld. (...)

Onze lezers zullen zich welligt herinneren, dat de zienswijze van v.R. ofschoon er in de hoofdtrekken geen verschil bestond, toch op sommige onderwerpen niet altijd geheel met de onze overeenkwam: des te aangenamer was ons dan ook, bij den aanvang dezes jaars, zijne toetreding als vaste medewerker tot ons Tijdschrift, dat zich te kort in die op prijs gestelde aansluiting heeft mogen verheugen. Ook het Staatkundig en staathuishoudkundig jaarboekje heeft menige degelijke en nuttige bijdrage van zijne hand ontvangen. 